\title{
Genome-Centric Analysis of Microbial Populations Enriched by Hydraulic Fracture Fluid Additives in a Coal Bed Methane Production Well
}

\author{
Steven J. Robbins ${ }^{1 *}$, Paul N. Evans ${ }^{1}$, Donovan H. Parks ${ }^{1}$, Suzanne D. Golding ${ }^{2}$ and \\ Gene W. Tyson ${ }^{1 *}$ \\ ${ }^{1}$ Australian Centre for Ecogenomics, School of Chemistry and Molecular Biosciences, The University of Queensland, \\ Brisbane, QLD, Australia, ${ }^{2}$ School of Earth Sciences, The University of Queensland, Brisbane, QLD, Australia
}

\section{OPEN ACCESS}

Edited by:

Martin Koenneke,

University of Bremen, Germany

Reviewed by:

Harold J. Schreier,

University of Maryland Baltimore

County, USA

Martin Krüger

Federal Institute for Geosciences and

Natural Resources, Germany

*Correspondence:

Steven J. Robbins

steven.robbins@uqconnect.edu.au;

Gene W. Tyson

g.tyson@uq.edu.au

Specialty section:

This article was submitted to Microbial Physiology and Metabolism, a section of the journal Frontiers in Microbiology

Received: 03 March 2016 Accepted: 02 May 2016 Published: 08 June 2016

Citation:

Robbins SJ, Evans PN, Parks DH, Golding SD and Tyson GW (2016) Genome-Centric Analysis of Microbial

Populations Enriched by Hydraulic Fracture Fluid Additives in a Coal Bed Methane Production Well.

Front. Microbiol. 7:731.

doi: 10.3389/fmicb.2016.00731
Coal bed methane (CBM) is generated primarily through the microbial degradation of coal. Despite a limited understanding of the microorganisms responsible for this process, there is significant interest in developing methods to stimulate additional methane production from CBM wells. Physical techniques including hydraulic fracture stimulation are commonly applied to CBM wells, however the effects of specific additives contained in hydraulic fracture fluids on native CBM microbial communities are poorly understood. Here, metagenomic sequencing was applied to the formation waters of a hydraulically fractured and several non-fractured CBM production wells to determine the effect of this stimulation technique on the in-situ microbial community. The hydraulically fractured well was dominated by two microbial populations belonging to the class Phycisphaerae (within phylum Planctomycetes) and candidate phylum Aminicenantes. Populations from these phyla were absent or present at extremely low abundance in non-fractured CBM wells. Detailed metabolic reconstruction of near-complete genomes from these populations showed that their high relative abundance in the hydraulically fractured CBM well could be explained by the introduction of additional carbon sources, electron acceptors, and biocides contained in the hydraulic fracture fluid.

Keywords: coal bed methane, aminicenantes, OP8, phycisphaerae, methane, hydraulic fracturing, metagenomics

\section{INTRODUCTION}

Over the last decade, coal bed methane (CBM) has emerged as an important resource for meeting rising global energy demands. It is anticipated that consumption of natural gas will grow by $1.5 \%$ each year until 2040, the fastest growth of any fossil fuel resource (U.S. Energy Information Administration, 2013). CBM is generated through biotic and abiotic processes, however analysis of methane isotopic compositions from CBM reservoirs worldwide suggest that the majority of methane is derived from microbial activity, especially at shallow depths (Scott, 2002; Strąpoć et al., 2011; Golding et al., 2013). Despite its economic importance, our understanding of the microbial communities responsible for the conversion of coal to methane is limited, hampering our ability to engineer strategies for stimulating native microbial communities to produce additional methane.

To extract CBM, a vertical well is drilled $200-1000 \mathrm{~m}$ into a coal bed. Water and gas are simultaneously extracted from the well and the gas is separated from the water at the surface. In cases where the natural permeability of the coal does not allow for economical rates of 
extraction, stimulation techniques such as hydraulic fracture are commonly applied. Hydraulic fracture involves the injection of a fluid mixture into the well at high pressure to fracture the coal (Australian Department of the Environment, 2014). The hydraulic fracture fluid mix often contains biocides to inhibit the growth of undesirable microorganisms, namely sulfate reducers, which may cause corrosion of the well bore. Flow paths created by the new fractures are held open by a proppant (e.g., sand, ceramic, or walnut husks) contained in the fracturing fluid. A gelling agent, typically a polysaccharide polymer, is commonly included in the hydraulic fracture fluid to suspend the proppant to ensure that it disperses evenly within the seam. In order to remove the fracturing fluid from the well, a breaker (e.g., hydrogen peroxide, diammonium peroxydisulfate, or a hemicellulase enzyme) is added to the well to depolymerize the gelling agent. Once the fracturing fluid is removed from the well, a production pump is installed at the wellhead to begin dewatering of the CSG well.

Here, community profiles for 11 wells from across the Surat Basin were subjected to metagenomic sequencing and characterization to identify strategies to enhance CBM production. One well, PK-28, had been subjected to hydrofracture stimulation and showed clear differences in community composition to the other wells sampled. The use of additives such as gelling agents, breakers, and biocides in the hydraulic fracture process is commonplace, but it is unknown how these additives may affect CBM community structure. Sugar polymer-based gelling agents and sulfate-based breakers may enable the growth of microorganisms capable of using these compounds, while additives such as biocides are likely to select for specific microbial populations. Metabolic reconstruction of microbial populations enriched in the PK-28 well strongly suggest that this shift in community composition is the result of exposure to hydrofracture fluid additives.

\section{MATERIALS AND METHODS}

\section{Sample Collection}

Biomass was collected from 11 previously characterized CBM production wells in the Surat Basin, Australia for metagenomic characterization (Evans et al., 2015). Water chemistry and isotope measurements were also collected for comparison and are described in detail by Baublys et al. (2015). Prior to microbial sampling, temperature, $\mathrm{pH}$, and conductivity were measured using an Accumet multimeter (Fisher Scientific model 13636AP85). When these readings stabilized $(\sim 10-$ $20 \mathrm{~min}$ ), between 10 and $50 \mathrm{l}$ of production water were filtered through two sequential $142 \mathrm{~mm}$ stainless steel filter housings (\#YY3014236, Millipore, MA, USA) containing a 20 $\mu \mathrm{m}$ polypropylene prefilter followed by a $0.22 \mu \mathrm{m}$ nitrocellulose filter. Both filters were folded aseptically, placed into separate falcon tubes, and frozen on dry ice for transport back to the laboratory.

\section{DNA Extraction, Sequencing, and Binning}

Metagenomic libraries were prepared using the Illumina Nextera XT DNA Sample Preparation kit and sequenced on twofifths of a lane on the Illumina HiSeq2000 platform in rapid mode $(2 \times 100$ bp paired end; 500 bp fragment size) producing an average of $4.1 \mathrm{~Gb}$ of paired-end data for each sample. Adapter clipping and merging of overlapping reads was performed using SeqPrep v2013-12-17 (https:// github.com/jstjohn/SeqPrep). Nesoni v0.99 (https://github.com/ VictorianBioinformaticsConsortium/nesoni) was used to remove homopolymers, quality trim bases with a Phred score $<20$, and discarding trimmed reads $\leq 30 \mathrm{bp}$. Assembly of the metagenome was performed using CLC Genomics Workbench v6.5 using default parameters.

Microbial community profiles for all metagenomes were generated by identifying sequencing reads from the 16S rRNA gene and mapping them to the Greengenes database using CommunityM (https://github.com/dparks1134/CommunityM) at a $97 \%$ threshold to define OTUs. Binning of the PK28 metagenome was carried out using DBB v1.0.0 (https:// github.com/dparks1134/DBB), which recruits scaffolds into population genomes based on similarity in GC-content, coverage, and tetranucleotide frequency. Genome completeness and contamination were estimated using the CheckM v0.9.6 lineagespecific workflow using default parameters (Parks et al., 2015).

\section{Statistical Analysis}

A heatmap showing the relative abundances of all OTUs present at a minimum of $1 \%$ in at least one sample was generated using STAMP (Parks et al., 2014). All statistical analyses were performed in $\mathrm{R}$ v3.1.2 ( $\mathrm{R}$ Core Team, 2013). Differences in OTU composition were further explored through principal components analysis of Hellinger transformed OTU relative abundances (Legendre and Gallagher, 2001) using the CRAN package vegan (Dixon, 2003).

\section{Phylogenetic Identification of Population Genomes}

In order to determine the phylogenetic affiliation of each metagenome bin, an approximate maximum-likelihood phylogenetic tree was constructed using FastTree v2.1.7 (Price et al., 2010) from a concatenated set of 83 bacterial single-copy marker genes (Soo et al., 2014) extracted from all PK-28 population genomes $\geq 70 \%$ completeness with $\leq 10 \%$ contamination as well as all IMG v4.0 genomes (Markowitz et al., 2012). Single-copy marker genes were identified and extracted from genomes using HMMER v3.1 (Finn et al., 2011). True maximum-likelihood trees were then re-inferred with RAxML (Stamatakis, 2006) including only IMG genomes of interest from 100 bootstrap replicates, using the PROTGAMMAWAG substitution model.

Maximum likelihood trees were also constructed with RAxML from $16 \mathrm{~S}$ rRNA gene sequences recovered from previous studies using the GTRGAMMA substitution model. For one recovered population, Aminicenantes-PK28, the 16S rRNA gene tree was constructed for the Aminicenantes phylum from 100 bootstrap replicates using near-full length (>1400 bp) 16S rRNA genes recovered in previous studies (Rinke et al., 2013; Farag et al., 2014; Gies et al., 2014; Sharon et al., 2015). The 16S rRNA gene sequences obtained from Sharon et al. (2015) were mined from a metagenome where an Aminicenantes population genome 
was recovered, but the 16S rRNA gene and population genome could not be linked (Sharon et al., 2015). Consequently, all four recovered $16 \mathrm{~S}$ rRNA gene fragments identified in the metagenome were included in the tree. A $16 \mathrm{~S}$ rRNA gene fragment ( $\sim 250 \mathrm{bp}$ ) extracted from the Aminicenentates-PK28 population genome was placed into the full length reference tree by parsimony insertion in ARB (Ludwig et al., 2004). Members of the phylum Acidobacteria were used as an outgroup based on a previous analysis showing this phylum to be a sister group to the Aminicenantes (Rinke et al., 2013).

\section{Population Genome Annotation and Metabolic Reconstruction}

Population genomes were annotated using Prokka v1.8 (Seemann, 2014) and IMG v4.1 (Markowitz et al., 2012). In parallel, open reading frames (ORFs) were identified using Prodigal v2.60 (Hyatt et al., 2010) and the resulting protein sequences were compared to Uniref90 (Suzek et al., 2007), COG (Tatusov et al., 2003), Pfam (Finn et al., 2014), and TIGRfam (Haft et al., 2013) using BLASTP (Altschul et al., 1997) and HMMER (Finn et al., 2011), respectively. Carbohydrate active enzymes (CAZY) were identified with dbCAN (Yin et al., 2012) using BLASTP (Altschul et al., 1997) with an $e$-value cut-off of $1 \mathrm{e}^{-10}$ and a coverage fraction cut-off of 0.5 . Peptidase families were identified by searching sequences annotated as peptidases against the MEROPS peptidase database using BLASTP (Rawlings et al., 2014). A sequence was assigned to the protein family of its best hit as long as the hit had an $e$-value threshold of $\leq 1 \mathrm{e}^{-20}$.

\section{RESULTS}

\section{CBM Formation Water Sampling and Community Profiling from Metagenomes}

Metagenomic datasets averaging $4.1 \pm 0.6 \mathrm{~Gb}$ of pairedend data were generated for formation waters collected from 11 CBM wells located in the Surat Basin, Queensland, Australia (Figure 1; Table 1). One of these wells, PK-28, had been subjected to hydraulic fracture stimulation in September of 2011. The hydraulic fracture fluid was injected and removed after $\sim 2$ weeks. However, no gas or water was extracted from PK-28 well until July 2013, approximately 4 months prior to sampling. In order to identify differences in the microbial community composition of the hydraulically fractured and non-fractured wells, community profiles for each formation water sample were generated by classifying 16S rRNA gene sequences from the metagenomic datasets (Figure 2). Operational taxonomic units (OTUs) from the actinobacterial order OPB41 (2-30\%) and methanogens from the Euryarchaeotal family Methanobacteriaceae (0-39\%) were typically dominant in all wells. In contrast, the PK-28 microbial community was dominated by OTUs belonging to the Planctomycetes class Phycisphaerae (9\%), the candidate phylum Aminicenantes order OPB95 (11\%), the actinobacterial order OPB41 (10\%), and hydrogenotrophic methanogens from the family Methanobacteriaceae (11\%). Comparison of the PK-28
TABLE 1 | CBM wells sampled from the Surat Basin.

\begin{tabular}{llll}
\hline Site ID & Site name & Latitude & Longitude \\
\hline AG-13 & Argyle 13 & -26.9134 & 150.4656 \\
AG-31 & Argyle 31 & -26.8991 & 150.4606 \\
BB-3 & Ben Bow 3 & -26.4411 & 149.3893 \\
BV-3 & Bellevue 3 & -26.7275 & 150.3090 \\
BV-9 & Bellevue 9 & -26.7104 & 150.2720 \\
BS-19 & Berwyndale South 19 & -26.8675 & 150.3086 \\
BS-36 & Berwyndale South 36 & -26.8546 & 150.3103 \\
CD-8 & Codie 8 & -27.0061 & 150.3916 \\
CX-10 & Coxon Creek 10 & -26.3686 & 149.0963 \\
PK-28 & Pickanjinnie 28 & -26.5821 & 149.1209 \\
WP-3 & Washpool Creek 3 & -26.6407 & 149.2323 \\
\hline
\end{tabular}

community composition to that of the other wells using principal components analysis showed that PK-28 clustered away from the other wells, indicating that its overall microbial community was atypical compared to the rest of the basin (Figure 3). The difference in the PK-28 community composition was primarily driven by the Aminicenantes and Phycisphaerae populations. The Aminicenantes were identified only in wells BB-3, WP-3, and BV-9 while the Phycisphaerae were identified in all wells other than WP-3 and BV-9. However, they only reached an abundance of $>0.1 \%$ in PK-28. Wells WP-3 and AG-13 also appeared to be somewhat atypical compared to the rest of the basin (Figure 3). These wells showed higher abundances of thermophilic populations from the family Thermodesulfovibrionaceae and genus Methanothermobacter, as well as a higher abundance of the class OPB41.

\section{PK-28 Population Genome Binning}

De novo assembly of the paired-end data for PK-28 produced 52,312 scaffolds $\geq 500 \mathrm{bp}$ with an N50 value of $3831 \mathrm{bp}$. A total of 11 population genomes with $\geq 70 \%$ completeness and $\leq 10 \%$ contamination were obtained by partitioning scaffolds based on GC-content, tetranucleotide frequency, and coverage (Table 2). These genomes span the majority of dominant populations identified in the $16 \mathrm{~S}$ rRNA gene community profile, with the exception of Caldiserica. The coverage of the population genomes generally matched the expected relative abundances, with coverage being highest for members of the family Methanobacteriaceae, followed by the Phycisphaerae and Aminicenantes. The Aminicenantes (AminicenantesPK28), and Phycisphaerae (Phycisphaerae-PK28) population genomes were targeted for detailed metabolic characterization to determine why these microorganisms were enriched in the hydraulically fractured well. Both the Aminicenantes-PK28 and Phycisphaerae-PK28 population genomes have been deposited in IMG under IDs 2593339135 and 2593339136 respectively.

\section{Phylogenetic Placement of Phycisphaerae-PK28 Population Genome}

The approximate maximum-likelihood phylogenetic tree constructed with FastTree placed Phycisphaerae-PK28 (Table 2) 


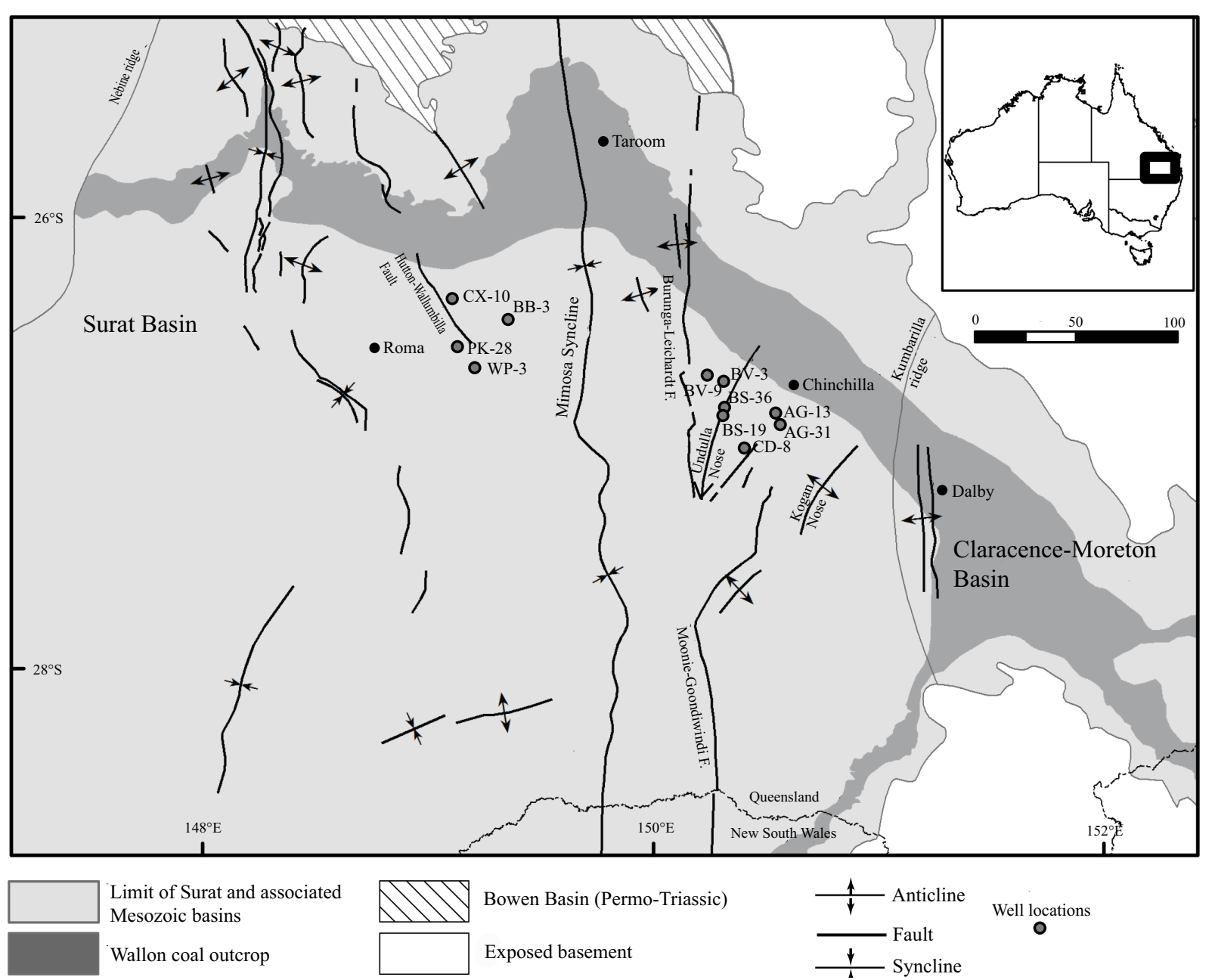

FIGURE 1 | Map of the Surat Basin (Queensland, Australia) showing the locations of CBM production wells sampled for metagenomic sequencing. Map modified from Hamilton et al. (2014).

within the Planctomycetes phylum next to Phycisphaerae mikurensis (Fukunaga et al., 2009). A true maximum likelihood tree inferred using all IMG Phycisphaerae genomes confirms this placement (Figure 4A). In order to more precisely determine its taxonomic affiliation, a 16S rRNA gene tree was constructed (Figure 4B) from the full-length rRNA gene sequence from Phycisphaerae-PK28 and additional Planctomycete sequences obtained from the Greengenes database (Desantis et al., 2006). This analysis placed Phycisphaerae-PK28 in the candidate order MSBL9.

\section{Phylogenetic Placement of Aminicenantes-PK28 Population Genome}

The approximate maximum-likelihood phylogenetic tree constructed with FastTree placed Aminicenantes-PK28 within the candidate phylum Aminicenantes (Figure 5A). Three Aminicenantes genomes have been sequenced to date (Rinke et al., 2013; Sharon et al., 2015), but there are no cultured representatives of this lineage. Previous phylogenetic analysis of the Aminicenantes using $16 \mathrm{~S}$ rRNA gene sequences (>800 bp in length) identified several putative subgroups within the candidate phylum, including four proposed classes and eight orders (Farag et al., 2014). Reconstruction of this phylogeny with the addition of 16S rRNA gene sequences from the three publically available Aminicenantes genomes revealed that these genomes belong to two distinct orders, HMMV and SHA-124, within the class OP8-1 (Figure 5B). Parsimony insertion of a $16 \mathrm{~S}$ rRNA gene fragment from the Aminicenantes-PK28 population genome places it within the order OPB95, within the proposed class OP8-1.

\section{Carbon Metabolism}

Differences in the PK-28 well community could result from the introduction of additional carbon sources in the hydraulic fracture fluid, enriching microorganisms best able to utilize the foreign organic matter. The vast majority of fluid is made up of water and inorganic proppant. In addition, the galactomannan polymer guar was used as a gelling agent. In order to determine 


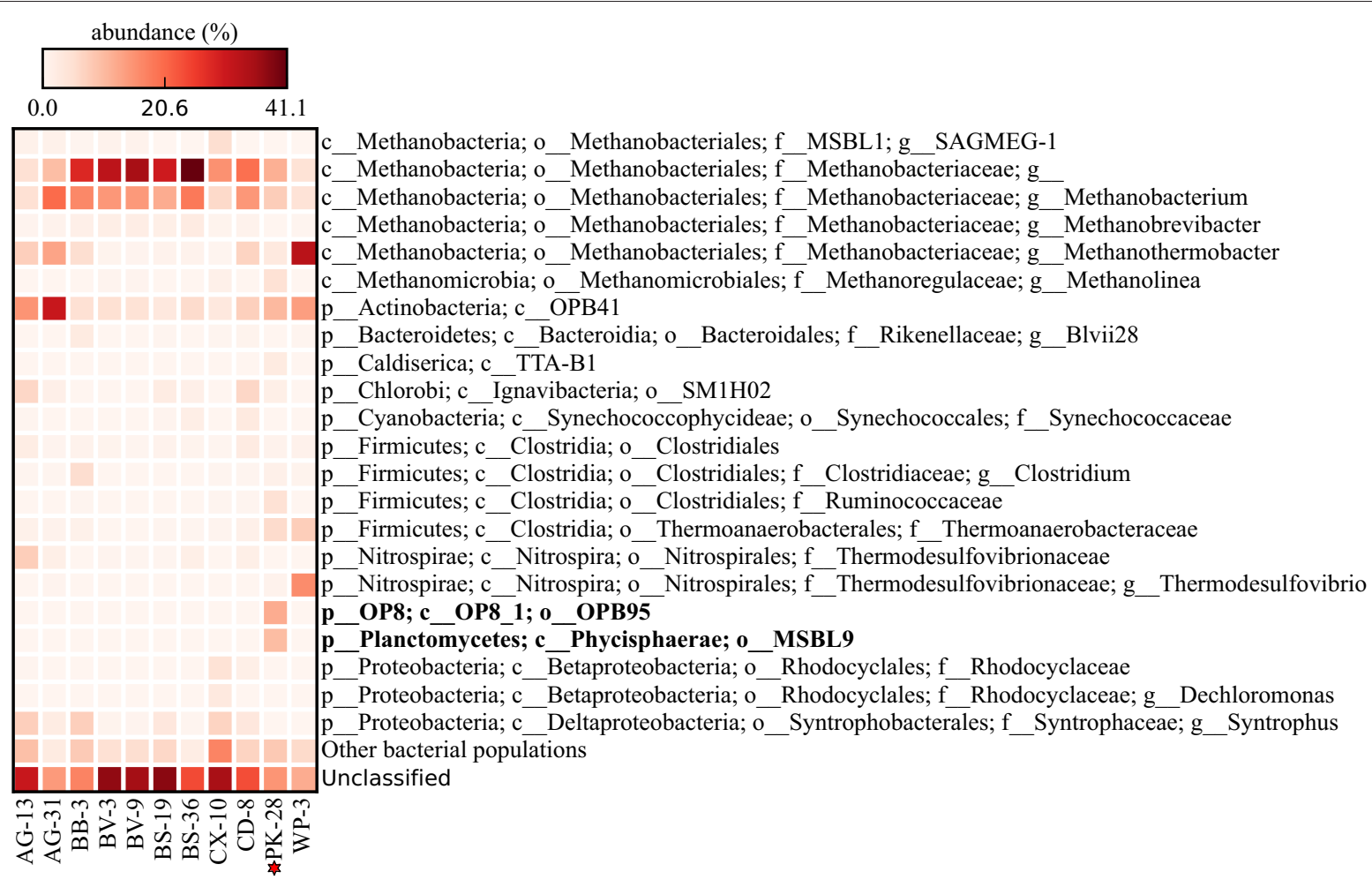

FIGURE 2 | Heatmap of the relative abundance of community members (operational taxonomic unit; OTU) from each of eleven formation waters sampled for microbial community profiling. Each row represents an OTU clustered at $97 \%$ identity. Only OTUs present at $\geq 1 \%$ relative abundance in at least one sample are shown. Reads that did not match the reference database at $\geq 97 \%$ identity were designated as unmapped.

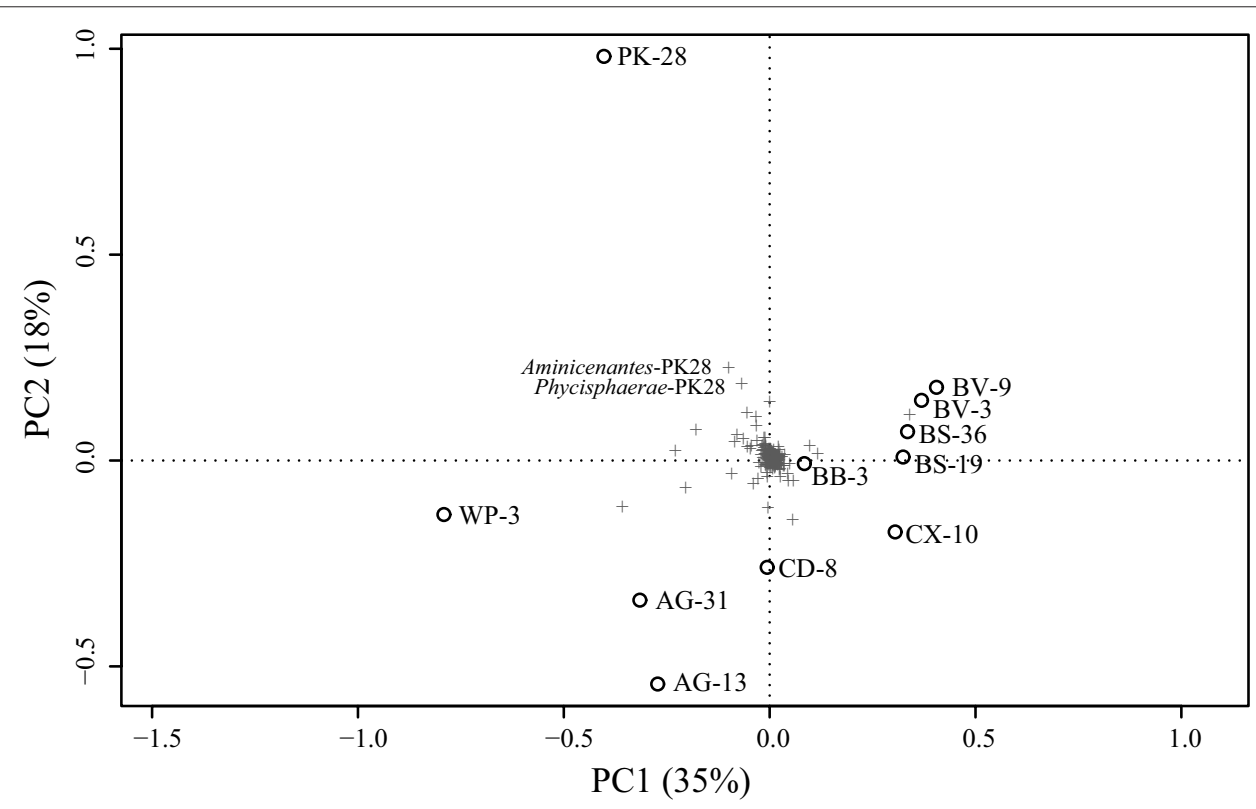

FIGURE 3 | PCA of Hellinger transformed OTU relative abundances for each formation water sample. Clustering of PK-28 away from the other wells appears to be driven by the abundance of Phycisphaerae-PK28 and Aminicenantes-PK28 which are not present at $>0.1 \%$ in any other well (Figure 2). Plus signs represent individual OTUs and circles represent well samples. 
TABLE 2 | Phylogenetic identification of population genomes and estimates of genome completeness and contamination.

\begin{tabular}{|c|c|c|c|c|c|c|c|c|}
\hline $\begin{array}{l}\text { Population genome } \\
\text { ID }\end{array}$ & Phylum & Lowest taxonomic classification & $\%$ Completeness & $\%$ Contamination & \# Scaffolds & $\begin{array}{l}\text { Genome size } \\
\text { (Mbp) }\end{array}$ & $\%$ GC & Coverage \\
\hline 0 & Planctomycetes & c_Phycisphaerae & 95.5 & 0 & 31 & 2.9 & 55.3 & 373 \\
\hline 1 & Ignavibacteriae & p_lgnavibacteriae & 96.9 & 2.2 & 73 & 3.1 & 41.6 & 36 \\
\hline 2 & Firmicutes & f__Peptococcaceae & 91.1 & 0.5 & 36 & 2.0 & 62.3 & 113 \\
\hline 3 & Aminicenantes & p_Aminicenantes & 88.0 & 2.5 & 73 & 2.5 & 53.5 & 301 \\
\hline 5 & Actinobacteria & p_Actinobacteria & 79.6 & 1.1 & 41 & 1.5 & 67.8 & 177 \\
\hline 6 & Euryarchaeota & g_Methanothermobacter & 92.4 & 1.4 & 52 & 1.6 & 50.0 & 31 \\
\hline 8 & Euryarchaeota & f__Methanobacteriaceae & 100 & 0 & 18 & 1.5 & 40.6 & 450 \\
\hline 9 & Proteobacteria & c__Deltaproteobacteria & 76.7 & 6.3 & 170 & 2.2 & 64.9 & 42 \\
\hline 10 & Euryarchaeota & g_Methanothermobacter & 90.5 & 1.6 & 44 & 1.6 & 49.2 & 67 \\
\hline 11 & Proteobacteria & f__Methanomicrobiaceae & 78.1 & 0.7 & 44 & 1.5 & 57.5 & 175 \\
\hline 12 & Firmicutes & o_Clostridiales & 85.3 & 8.4 & 130 & 1.7 & 48.6 & 15 \\
\hline
\end{tabular}

whether the introduction of the galactomannon contributed to the enrichment of the Aminicenantes and Phycisphaerae groups, the presence of genes for the utilization of galactomannon as a carbon substrate were examined (Figures 6, 7). All genes required for the endo-hydrolysis of the mannan backbone of galactomannan (endo- $\beta$ i-mannanase) were identified in Phycisphaerae-PK28 (Figure 6), but not Aminicenantes-PK28 (Figure 7), and included representatives of glycosyl hydrolase (GH) families 5 and 76. In contrast, genes for the hydrolysis of terminal mannose residues (i.e., $\beta$-mannosidase) were identified in both population genomes, including GH families 2 and 113. The presence of $\beta$-galactosidases from GH family 2 in both population genomes, and GH 16 in Phycisphaerae-PK28, suggests that both Aminicenantes-PK28 and PhycisphaeraePK28 are able to cleave the galactose side groups from guar.

Hydrolysed mannose and galactose residues are likely to be fed into glycolysis. For example, hexokinase and mannose6P-isomerase in both microorganisms can be used to convert mannose to fructose-6P, an intermediate in glycolysis. In Aminicenantes-PK28, metabolism of galactose follows the Leloir pathway, whereby $\beta$-D-galactose is converted to UDPglucose by galactose mutarotase, galactokinase, galactose-1phosphate uridylyltransferase, and UDP-galactose-4-epimerase. Although neither galactose-1-phosphate uridylyltransferase or UDP-galactose-4-epimerase were identified in PhycisphaeraePK28, the presence of galactose mutarotase and galactokinase, as well as a sodium/galactose symporter, suggest that a route similar to the Leloir pathway is used to degrade galactose. In both microorganisms, the pyruvate generated through glycolytic degradation of mannose and galactose may be converted to acetyl-CoA by the action of pyruvate-ferredoxin oxidoreductase for use in a number of biosynthetic reactions. Alternatively, the presence of pyruvate-formate lyase in PhycisphaeraePK28 suggests that pyruvate may instead be converted to formate. Although no specific mechanism for generating formate was found in Aminicenantes-PK28, putative genes for formate dehydrogenase (i.e., hydrogenase- 3 and formate hydrogenylase) were identified and could be used to convert formate to hydrogen and carbon dioxide as terminal products of fermentation.

\section{Alternative Sugar Substrates}

In general, both Aminicenantes-PK28 and PhycisphaeraePK28 appear to be adapted to utilizing a variety of complex sugar polymers. An analysis of glycosyl hydrolases (GHs), carbohydrate binding modules (CBMs), carbohydrate esterases (CEs), and polysacharaide lyases (PLs) in all PK28 population bins revealed that both Aminicenantes-PK-28 and PhycisphaeraePK28 contained higher proportions of carbohydrate active enzymes compared to other members of the PK-28 microbial community, suggesting that they are highly adapted to utilizing sugar polymers as a carbon and energy source (Table 3). Aminicenantes-PK28 and Ignavibacteriae-PK28 (population genome 1) also devoted a high proportion of their genome to carbohydrates degradation. However, Ignavibacteriae-PK28 was not present at high proportion in the PK-28 microbial community $(\sim 1.5 \%)$.

Several genes encoding pectin-degrading enzymes were identified in both Aminicenantes-PK28 and Phycisphaerae-PK28, although the carbohydrate substrate range of PhycisphaeraePK28 appeared to be more diverse. In both microorganisms, genes encoding polygalacturonases from $\mathrm{GH}$ family 28 were identified that could be used to cleave pectin into galacturonate monomers. However, in Phycisphaerae-PK28, multiple rhamnogalacturonan and pectate lyases from families 1,9 , and 10 were also identified that could be used to degrade alternative forms of pectin. Although it is unclear how Aminicenantes-PK28 processes the galacturonate residues released from pectin cleavage, the presence of genes encoding 5-keto-4-deoxyuronate isomerase $(k d u L), 2$-dehydro-3-deoxyD-gluconate 5-dehydrogenase $(k d u D), 2$-keto-3-deoxygluconate kinase ( $k d g k$ ), and 2-keto-3-deoxy-6-phosphogluconate aldolase $(k d p g)$ in Phycisphaerae-PK28 suggest that galacturoate is likely to be converted to 2-dehydro-3-hydroxy-D-gluconate for use in the pentose phosphate pathway. Additionally, the presence of endo-acting xylanases from GH family 43 , as well as $\beta$ xylosidases capable of cleaving terminal xylose residues, suggest 
A

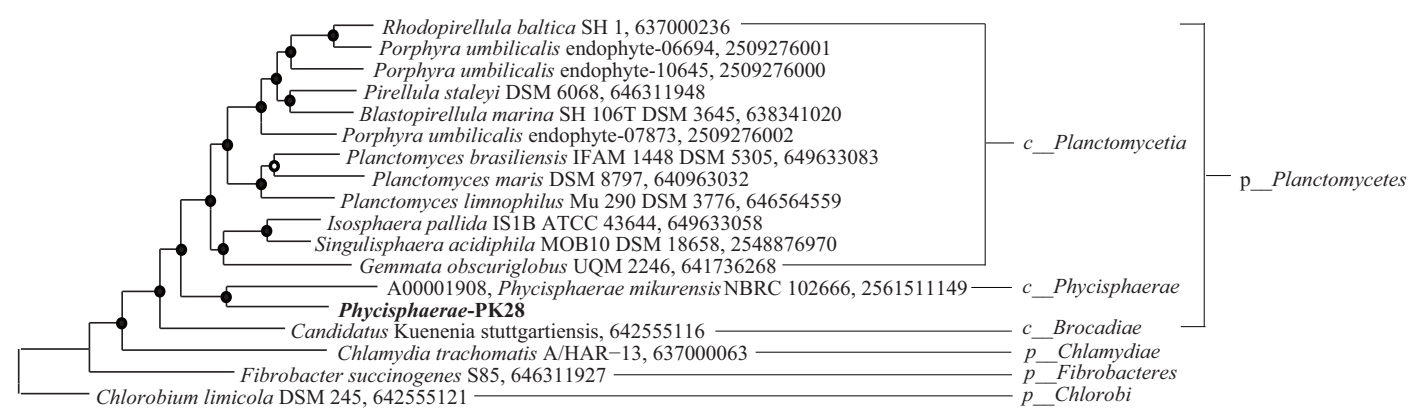

$\underline{0.10}$

B

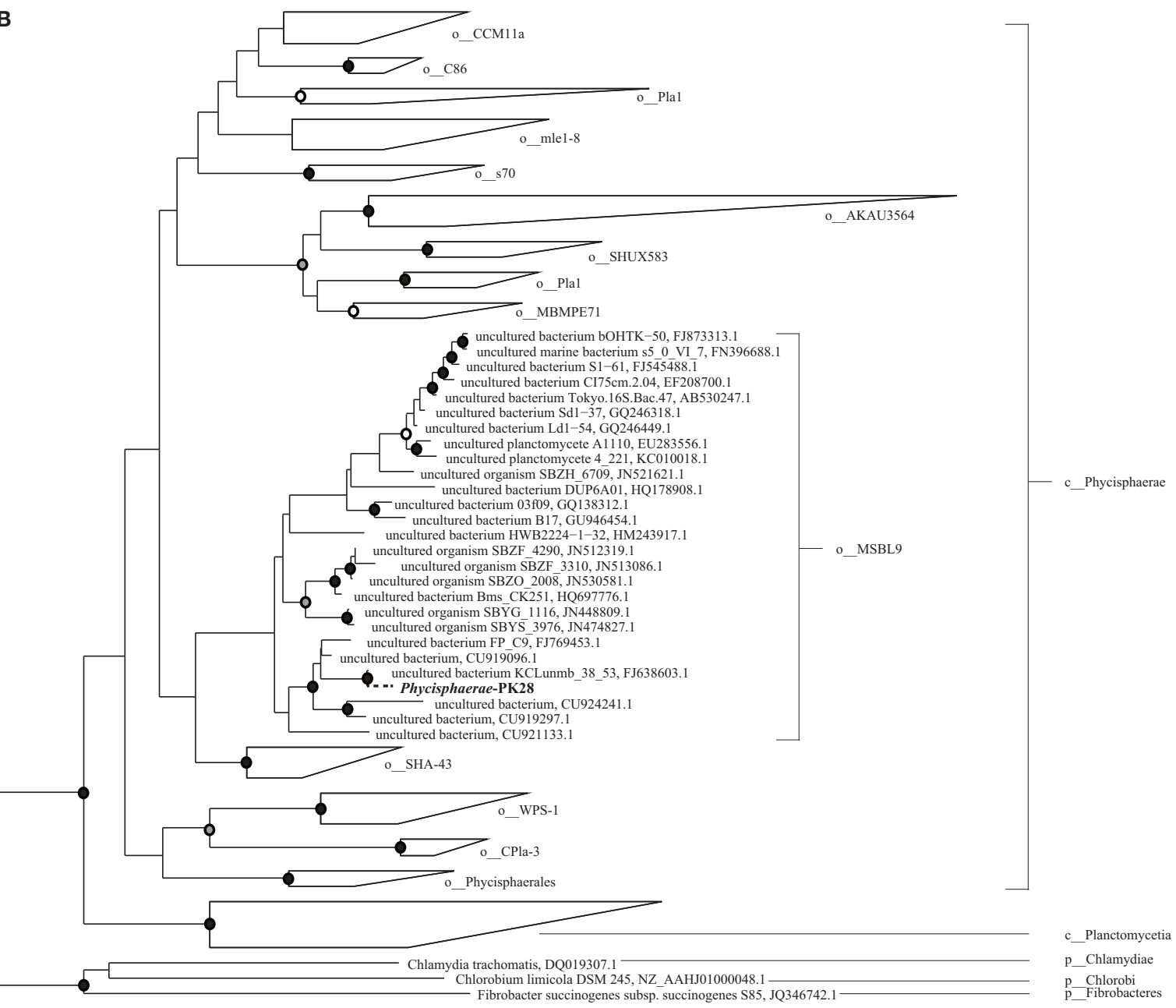

FIGURE 4 | Maximum likelihood phylogenetic trees showing the placement of Phycisphaerae-PK28 within the phylum Planctomycetes using (A) a concatenated set of 83 bacterial single-copy marker genes and (B) 16S rRNA gene sequences from Phycisphaerae-PK28 and members of the phylum Planctomycetes. These analyses place Phycisphaerae-PK28 into the order MSBL9 within the class Phycisphaerae. NCBI accession numbers and IMG genome IDs are listed to the right of each sequence. In both trees, white, gray, and black circles represent nodes with $70-80 \%, 80-90 \%$, and $>90 \%$ bootstrap support values respectively. For the concatenated marker gene tree, members of the phyla Chlamydiae, Fibrobacter, and Chlorobi were used to root the tree. 


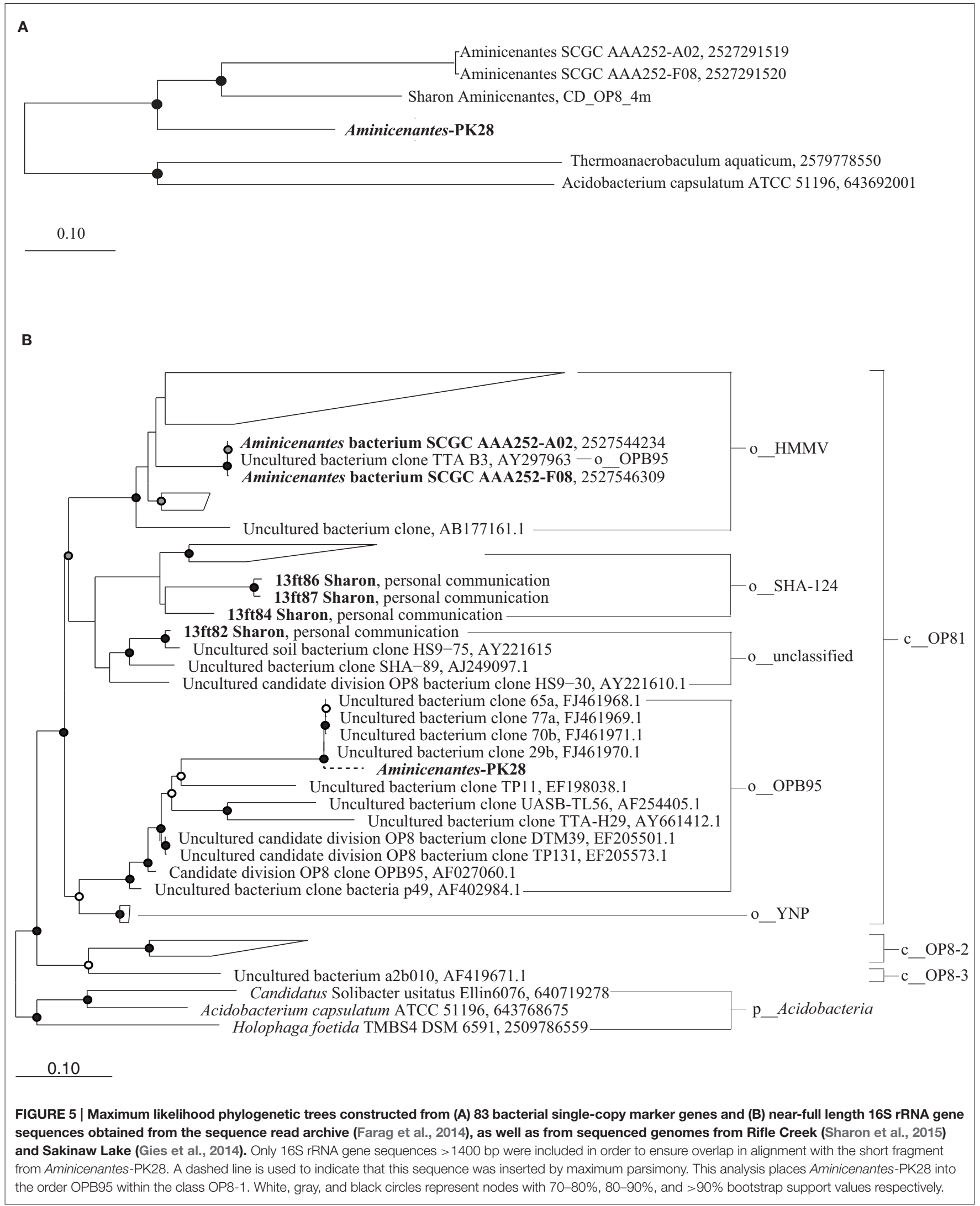




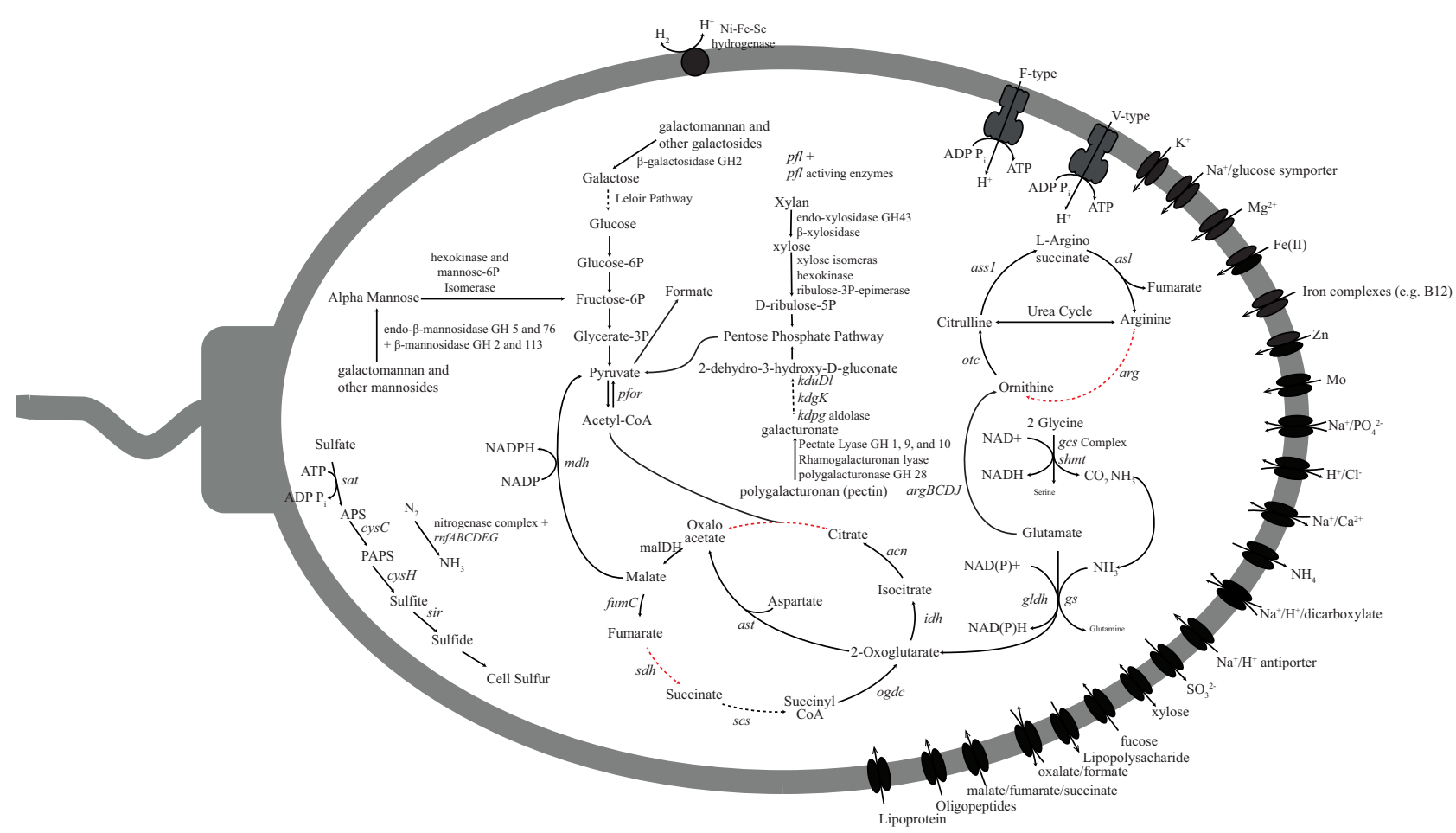

FIGURE 6 | Metabolic reconstruction of the Phycisphaerae-PK28 population genome. Sugar polymers such as galactomannan (guar), xylan (hemicellulose), and polygalacturonan (pectin) may be degraded and directed toward glycolysis for energy production. The pyruvate generated through glycolysis is likely to be converted to formate by pyruvate-formate lyase. Nitrogen and sulfur could be acquired through nitrogen fixation and assimilatory sulfate reduction. Abbreviations used: fumC, fumarate hydratase; sdh, succinate dehydrogenase; scs, succinyl-CoA synthetase; ogdc, oxoglutarate dehydrogenase complex; idh, isocitrate dehydrogenase; can, citrate hydro-lyase; cs, citrate synthase; ass 1, argininosuccinate synthase; otc, ornithine transcarbamylase; arg, arginase; asl, argininosuccinate lyase; pfor, pyruvate-ferrodoxin oxidoreductase; $m d h$, malate dehydrogenase; pfl, pyruvate-formate lyase; rnf, Rnf electron transport complex; ast, aspartate transaminase; gs, glutamate synthetase; gldh, glutamate dehydrogenase; gcs, glycine cleavage system; shmt, serine hydroxmethyltransferase; argB, acetylglutamate kinase; $\arg \mathrm{C}, \mathrm{N}$-acetyl-glutamate semialdehyde dehydrogenase; argD, N-acetylornithine aminotransferase; argJ, arginine biosynthesis bifunctional protein; sat, sulfate adenylyltransferase; $c y s C$, adenylylsuflate kinase; $c y s H$, phosphoadenylylsufate reductase; and sir, assimilatory sulfite reductase.

that Phycisphaerae-PK28 is able to hydrolyse xylan. Xylose monomers liberated from this process can be converted by xylose isomerase $(x y l A)$, hexokinase, and ribulose-3P-epimerase (rpe) to D-ribulose-5P, an intermediate in the pentose phosphate pathway that can be directed into glycolysis.

\section{Amino Acid Metabolism}

Oligopeptide transporters are present in both AminicenantesPK28 and Phycisphaerae-PK28, and both microorganisms appear to be able to utilize select amino acids, such as glycine (glycine cleavage system), glutamate (glutamate dehydrogenase, gldh; and glutamine synthetase, $g s$ ), and aspartate (aspartate transaminase, ast). Additionally, genes encoding multiple proline transporters (ABC-type and proline permease) were also identified in Aminicenantes-PK28. The presence of genes encoding pyrroline5-carboxylate reductase (pcra) and aspartate transaminase (ast) suggest that proline is converted to glyoxylate and pyruvate. In Phycisphaerae-PK28, nearly all of the 21 peptidases identified were linked to cell signaling or the modification/maturation of specific proteins, rather than peptide degradation. In contrast, 36 of the 80 peptidases identified in Aminicenantes-PK28 are associated with the degradation of oligopeptides, including representatives from peptidase families M3, M14, M20, M28, M55, S14, S16, S41, S46, C1B, C69, and T1B. Interestingly, five genes encoding representatives of peptidase family M23 used to degrade the cell walls of other bacteria were identified in Aminicenantes-PK28, which suggests a possible role in peptide scavenging from dead cells.

\section{Nitrogen, Sulfur, and Oxygen Metabolism}

In order to determine whether Aminicenantes-PK28 or Phycisphaerae-PK28 could carry out either aerobic or anaerobic respiration, the presence of genes for oxidative phosphorylation (electron transport cytochromes), dissimilatory sulfate and sulfite reduction (dissimilatory sulfite reductase; $d s r$ ), and dissimilatory nitrate and nitrite reduction (dissimilatory nitrate, nar; or nitrite reductase, $n r f$ ) were examined. The absence of these genes suggests that neither Aminicenantes-PK28 nor Phycisphaerae-PK28 is able to respire using these electron acceptors. However, genes for assimilatory acquisition of sulfur and nitrogen acquisition were identified. For example, genes for assimilatory sulfate reduction were present in both 


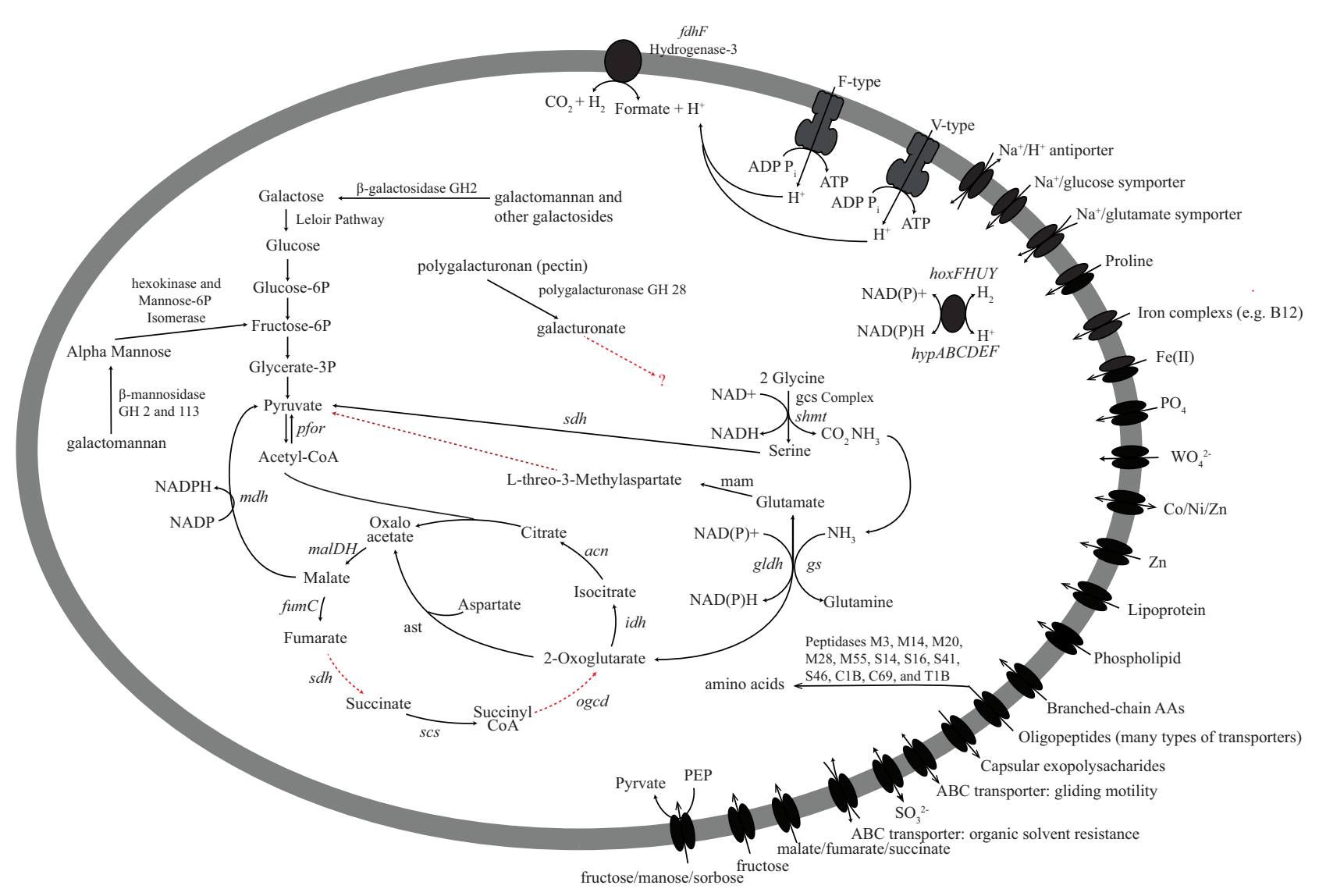

FIGURE 7 | Metabolic reconstruction of the Aminicenantes-PK28 population genome. The sugar polymers galactomannan (guar) and polygalacturonan (pectin) may be degraded. Galactomannan is likely to be directed toward glycolysis for energy production. Although polygalacturonases were identified, it is not clear how Aminicenantes-PK28 processes galacturonate. Several peptidases involved in the degradation of oligopeptides were identified, including family M23, which is involved in the lysis of bacterial cells. These findings suggest that Aminicenantes-PK28 may scavenge non-viable cells. Abbreviations used: fumC, fumarate hydratase; sdh, succinate dehydrogenase; scs, succinyl-CoA synthetase; ogdc, oxoglutarate dehydrogenase complex; idh, isocitrate dehydrogenase; can, citrate hydro-lyase; cs, citrate synthase; $m d h$, malate dehydrogenase; pfor, pyruvate-ferrodoxin oxidoreductase; ast, aspartate transaminase; gs, glutamate synthetase; gldh, glutamate dehydrogenase; gcs, glycine cleavage system; shmt, serine hydroxmethyltransferase; sdh, serine dehydrogenase; fdh, formate dehydrogenase.

microorganisms, including sulfate adenylyltransferase (sat), adenylylsuflate kinase $(\operatorname{cys} C)$, phosphoadenylylsufate reductase $(\mathrm{cys} H)$, and a putative assimilatory sulfite reductase (sir). Although sulfate may be present in low concentrations in coal strata, peroxidisulfate was also introduced as a breaker to depolymerize the guar gelling agent and may contribute to the cell sulfur pool. The presence of a full operon for an iron-molybdenum nitrogenase (nif) was identified, as well as a nitrogenase-associated $r n f$ electron transport complex, suggests that Phycisphaerae-PK28 is able to fix nitrogen.

\section{Effect of Biocide}

Kathon, a mixture of 5-chloro-2-methyl-4-isothiazolin-3one and 2-methyl-4-isothiazolin-3-one, was included in the fracturing fluid to inhibit microbial growth. The chemical mechanism of this biocide is complex, but is known to act by disrupting the cell membrane, cleave thiol bonds, generate free radicals, and inactivate a number of key metabolic enzymes, including pyruvate dehydrogenase, 2-oxoglutarate dehydrogenase, succinate dehydrogenase, $\mathrm{NADH}$ dehydrogenase, lactate dehydrogenase, and alcohol dehydrogenase (Williams, 2007). Of these enzymes, Aminicenantes-PK28 and Phycisphaerae-PK28 appear to contain only genes for 2-oxoglutarate dehydrogenase.

\section{Water Chemistry and Isotopic Analysis}

Geochemical parameters with the potential to influence microbial community structure were measured (Table 4) as part of a larger investigation into the geochemistry of Surat Basin CBM production waters (Baublys et al., 2015). Some wells were sampled at multiple time points as part of a time series, with one time point paired with samples for microbial analysis. Few systematic trends were evident across the basin, but carbonate tended to be lower in wells located in the western Surat Basin (avg. 1031) compared to the east (avg. 1787). The $\mathrm{pH}$ of the wells ranged from 7.6 in well WP-3 to 8.67 in CX-10. Most wells 
TABLE 3 | Summary of the total number of carbohydrate-active enzymes in each population genome, including glycosyl hydrolases, carbohydrate esterases, polysaccharide lyases, and enzymes containing carbohydrate binding modules.

\begin{tabular}{|c|c|c|c|c|c|c|}
\hline \multirow[t]{2}{*}{ Population genome ID } & \multirow[t]{2}{*}{ Lowest taxonomic classification } & \multicolumn{2}{|c|}{ Glycosyl hydrolases } & \multicolumn{3}{|c|}{ Carbohydrate binding modules } \\
\hline & & Total GH hits & $\%$ GH ORFs & Total CBM hits & $\%$ CBM ORFs & Total ORFs \\
\hline 0 & c_Phycisphaerae & 113 & 4.69 & 39 & 1.62 & 2410 \\
\hline 1 & p_lgnavibacteriae & 89 & 3.15 & 24 & 0.85 & 2822 \\
\hline 2 & f__Peptococcaceae & 9 & 0.47 & 10 & 0.52 & 1908 \\
\hline 3 & p_Aminicenantes & 42 & 2.12 & 15 & 0.76 & 1981 \\
\hline 5 & $\mathrm{p} \_$Actinobacteria & 4 & 0.27 & 3 & 0.20 & 1472 \\
\hline 6 & g_Methanothermobacter & 1 & 0.06 & 1 & 0.06 & 1637 \\
\hline 8 & f__Methanobacteriaceae & 2 & 0.13 & 0 & 0 & 1593 \\
\hline 9 & c__Deltaproteobacteria & 12 & 0.61 & 1 & 0.05 & 1972 \\
\hline 10 & g_Methanothermobacter & 1 & 0.06 & 0 & 0 & 1676 \\
\hline 11 & f__Methanomicrobiaceae & 0 & 0 & 1 & 0.06 & 1589 \\
\hline 12 & o__Clostridiales & 8 & 0.45 & 12 & 0.67 & 1796 \\
\hline \multirow[t]{2}{*}{ Population genome ID } & Lowest taxonomic classification & \multicolumn{2}{|c|}{ Carbohydrate esterases } & \multicolumn{3}{|c|}{ Polysaccharide lyases } \\
\hline & & Total CE hits & $\%$ CE ORFs & Total PL hits & $\%$ PL ORFs & Total ORFs \\
\hline 0 & c_Phycisphaerae & 17 & 0.71 & 13 & 0.54 & 2410 \\
\hline 1 & p_lgnavibacteriae & 15 & 0.53 & 7 & 0.25 & 2822 \\
\hline 2 & f__Peptococcaceae & 6 & 0.31 & 0 & 0 & 1908 \\
\hline 3 & $\mathrm{p}$ __Aminicenantes & 10 & 0.50 & 0 & 0 & 1981 \\
\hline 5 & p_Actinobacteria & 2 & 0.14 & 1 & 0.07 & 1472 \\
\hline 6 & g__Methanothermobacter & 2 & 0.12 & 0 & 0 & 1637 \\
\hline 8 & f__Methanobacteriaceae & 0 & 0 & 0 & 0 & 1593 \\
\hline 9 & c__Deltaproteobacteria & 2 & 0.10 & 0 & 0 & 1972 \\
\hline 10 & g_Methanothermobacter & 0 & 0 & 0 & 0 & 1676 \\
\hline 11 & f__Methanomicrobiaceae & 0 & 0 & 0 & 0 & 1589 \\
\hline 12 & o__Clostridiales & 4 & 0.22 & 0 & 0 & 1796 \\
\hline
\end{tabular}

The total number of gene hits to each category is shown, as well as the percentage of all open reading frames (ORFs) devoted to that carbohydrate active enzyme (CAZY) category.

showed temperature values of $\sim 35^{\circ} \mathrm{C}$, with wells $\mathrm{AG}-13, \mathrm{AG}-31$, WP-3, and PK-28 reaching above $40^{\circ} \mathrm{C}$. Conductivity showed more variability, ranging from $4.40 \mathrm{mS}$ in AG-13 to $13.41 \mathrm{mS}$ in WP-3, indicating substantially higher salinity in that well. Consistent with this finding, WP-3 also shows the highest levels of sodium, chloride, potassium, magnesium, and total iron. As described by Baublys et al. (2015), trends within the isotopic data (Table 5) are primarily reflective of the region from which the water is derived. Consistent with the injection of additional water and carbon into the well, PK-28 shows a younger water age than any other well and a higher percentage of modern carbon.

\section{DISCUSSION}

Stimulation of additional biogenic methane from CBM production wells is likely to require a detailed understanding of the in situ microbial communities. Although a number of studies have characterized the microbial communities present in unperturbed CBM production wells, this is the first study to examine a CBM microbial community after hydraulic fracture stimulation. Clear differences in community composition were identified between PK-28 and wells that had not been exposed to hydraulic fracture additives. Metagenomic analysis revealed strong links between potential carbon substrates introduced in the hydraulic fracturing fluid and the metabolism of the dominant bacterial populations. These findings suggest that hydraulic fracturing has a marked effect on the composition and metabolism of CBM microbial communities.

The most significant compositional difference between PK-28, the hydraulically fractured well, and the 10 other CBM production wells was the presence of representatives from the bacterial candidate phylum Aminicenantes (11\%) and class Phycisphaerae (9\%) within the phylum Planctomycetes. These were present at $<0.5 \%$ relative abundance in all non-fractured wells. Metabolic reconstruction of the Aminicenantes-PK28 and Phycisphaerae-PK28 genomes revealed the presence of genes for the degradation of galactomannon (i.e., guar), a common additive in hydraulic fracture fluid. Orem et al. (2014) have shown that the organic constituents of hydraulic fracture fluid can persist in the coal bed for several months after the fluids have been removed. Therefore, as water had only been extracted from 
TABLE 4 | Water chemistry CBM production waters.

\begin{tabular}{|c|c|c|c|c|c|c|c|c|c|c|c|c|c|c|c|c|}
\hline $\begin{array}{l}\text { Site } \\
\text { ID }\end{array}$ & $\begin{array}{l}\text { Date } \\
\text { sampled }\end{array}$ & $\mathrm{pH}$ & $\begin{array}{c}\text { Conductance } \\
\text { (mS) }\end{array}$ & $\begin{array}{l}\text { Temperature } \\
\qquad\left({ }^{\circ} \mathrm{C}\right)\end{array}$ & $\mathrm{HCO}_{3}$ & Cl & $\mathrm{Ca}$ & Mg & $\mathrm{Na}$ & $\mathbf{K}$ & $\mathbf{F}$ & $\begin{array}{l}\text { Total } \\
\text { N }\end{array}$ & $\begin{array}{c}\text { Total } \\
\text { P }\end{array}$ & $\begin{array}{l}\text { Total } \\
\text { Fe }\end{array}$ & $\begin{array}{c}\text { Dissolved } \\
\mathrm{Fe}\end{array}$ & $\begin{array}{l}\text { Depth } \\
\text { (m) }\end{array}$ \\
\hline AG-13* & $11 / 27 / 2013$ & 8.21 & 4.40 & 41.3 & 2121 & 443 & 3 & $<1$ & 1020 & 4 & 4.6 & 0.9 & 0.03 & 0.70 & 0.08 & $261-615$ \\
\hline AG-31 & 5/08/2013 & 8.29 & 5.5 & 44.5 & 1841 & 799 & 4 & 1 & 1140 & 5 & 4.1 & 0.7 & 0.04 & 0.35 & $<0.05$ & 265-604 \\
\hline AG-31* & 11/27/2013 & 8.24 & 5.02 & 32.1 & 1865 & 790 & 4 & 1 & 1150 & 5 & 3.8 & 0.9 & 0.02 & 0.46 & 0.18 & 265-604 \\
\hline BB-3* & $11 / 25 / 2013$ & 7.85 & 7.97 & 36.0 & 980 & 1730 & 12 & 4 & 1530 & 86 & 2.1 & 1.0 & 0.04 & 4.48 & 0.37 & 515-835 \\
\hline BV-3 & $5 / 07 / 2013$ & 8.15 & 8.05 & 37.8 & 1390 & 1720 & 7 & 3 & 1680 & 7 & 2.8 & 1.2 & 0.04 & 0.59 & 0.17 & $172-480$ \\
\hline BV-3* & $11 / 28 / 2013$ & 8.28 & 8.18 & 36.1 & 1402 & 1650 & 7 & 3 & 1670 & 6 & 2.6 & 1.0 & 0.02 & 0.26 & 0.05 & $172-480$ \\
\hline BV-9 & $5 / 07 / 2013$ & 8.28 & 5.52 & 36.4 & 1512 & 1020 & 5 & 2 & 1140 & 5 & 2.6 & 1.2 & 0.04 & 5.12 & $<0.05$ & 189-527 \\
\hline BV-9* & 11/28/2013 & 8.36 & 5.72 & 35.0 & 1500 & 1040 & 5 & 2 & 1270 & 5 & 2.4 & 0.8 & 0.03 & 2.26 & $<0.05$ & 189-527 \\
\hline BS-19 & 5/06/2013 & 8.36 & 3.46 & 35.3 & 1280 & 510 & 2 & 1 & 762 & 3 & 4.9 & 0.8 & 0.03 & 1.64 & $<0.05$ & $362-566$ \\
\hline BS-19* & $11 / 27 / 2013$ & 8.43 & 3.65 & 34.4 & 1317 & 540 & 2 & $<1$ & 825 & 3 & 4.5 & 0.5 & 0.03 & 1.86 & 0.44 & $362-566$ \\
\hline BS-36 & 5/06/2013 & 8.39 & 5.11 & 36.1 & 1963 & 745 & 3 & 1 & 1140 & 4 & 4.2 & 1.6 & 0.08 & 1.54 & 0.07 & $309-617$ \\
\hline BS-36* & 11/27/2013 & 8.49 & 5.30 & 36.5 & 1951 & 770 & 3 & $<1$ & 1210 & 4 & 3.9 & 0.8 & 0.03 & 4.79 & 0.63 & $301-672$ \\
\hline CD-8* & 5/08/2013 & 8.49 & 4.61 & 30.2 & 2353 & 330 & 2 & 1 & 1000 & 4 & 4.9 & 0.4 & 0.05 & 2.28 & 0.41 & 460-804 \\
\hline CX $-10^{\star}$ & $11 / 25 / 2013$ & 8.67 & 3.46 & 31.4 & 1256 & 539 & 3 & $<1$ & 782 & 15 & 0.6 & 0.6 & 0.03 & 3.35 & $<0.05$ & $200-442$ \\
\hline PK-28* & $11 / 25 / 2013$ & 8.00 & 5.58 & 44.5 & 947 & 1260 & 9 & 1 & 1200 & 6 & 3.7 & 1.0 & 0.02 & 1.02 & 0.67 & $603-820$ \\
\hline WP-3 & $3 / 24 / 2011$ & 7.6 & 13.41 & 32.3 & 861 & 4280 & 38 & 9 & 2740 & 67 & - & - & - & - & - & 704-978 \\
\hline WP-3* & $11 / 25 / 2013$ & 7.90 & 7.00 & 42.9 & 939 & 1540 & 15 & 3 & 1400 & 31 & 3.9 & 1.4 & 0.02 & 36.0 & 0.06 & 704-978 \\
\hline
\end{tabular}

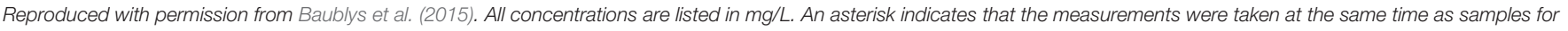
microbial analysis.

the well for $\sim 4$ months, after having been allowed to incubate for 2 years, it is likely that galactomannan polymer still resided in the well (Struchtemeyer and Elshahed, 2012). In addition, estimates for the doubling time of microbes present in the deep subsurface biosphere under energy-starved conditions range from a few years to several millennia (Hoehler and Jørgensen, 2013; Onstott et al., 2014), suggesting that the microbial community structure of the well is likely to remain largely static for years after the galactomannan is removed.

Genes for the endo-hydrolysis of galactomannon (i.e., endo-mannases) were identified in the Phycisphaerae-PK28 genome, indicating that it is primarily responsible for the depolymerization of guar into short oligosaccharides monomers. These genes were identified in only one other member of the PK-28 community, Ignavibacteriae-PK28, and it is unclear why this microorganism is not more abundant. However, we can speculate that Ignavibacteriae-PK28 was more susceptible to the biocide. The presence of $\beta$-galactosidases and $\beta$-mannosidases in the Aminicenantes-PK28 and Phycisphaerae-PK28 genomes suggest that both microorganisms are able to use mannose and galactose produced by galactomannan degradation. In Aminicenantes-PK28, a putative phosphotransferase system for the uptake of mannose was identified that could be used to absorb mannose into the cell. No such system was identified in Phycisphaerae-PK28. The application of a peroxidisulfate breaker to partially hydrolyse the gelling agent in the hydraulic fracture fluid prior to removal from the well was likely to release free mannose and galactose monomers for consumption, as well as cell sulfur for Phycisphaerae-PK28. The presence of genes encoding pyruvate-formate lyase in Phycisphaerae-PK28, and formate dehydrogenase in Aminicenantes-PK28, suggests that formate, hydrogen, and carbon dioxide are major end products of fermentation. This would provide an avenue for a syntrophic association with the dominant hydrogenotrophic methanogens in the PK-28 community belonging to the family Methanobacteriaceae. In support of this hypothesis, a previous $16 \mathrm{~S}$ rRNA gene amplicon based analysis of the water column of Sakinaw Lake (Canada) showed a statistical correlation between the Aminicenantes and hydrogenotrophic members of the order Methanomicrobiales (Gies et al., 2014). The unique ability of Aminicenantes-PK28 and Phycisphaerae-PK28 to ferment galactomannon in syntrophic association with a hydrogenotrophic methanogen, may have provided a selective advantage allowing these rare microorganisms to become enriched. Further support for the role of Aminicenantes and Phycisphaerae-PK28 in in-situ galactomannan degradation could be generated through the establishment of enrichment cultures seeded with CBM formation waters growing on galactomannan as a carbon substrate, potentially containing Kathon as a selective agent.

The ability to utilize a diverse array of polysaccharides, including guar-like polysaccharides, has been identified as a defining feature of Planctomycetes which are found in a variety of environments, including fresh and marine waters, hot springs, soils, and hydrocarbon contaminated environments (Yakimov et al., 2006; Abed et al., 2010, 2011; Lage and Bondoso, 2011; Tekere et al., 2013). Metabolic analysis of Phycisphaerae-PK28 showed that in addition to galactomannon, it has the potential to hydrolyse the xylose polymer xylan, as well as pectin. The ability to utilize complex sugars has been demonstrated previously in members of the Planctomycetes present within macroalgae-associated biofilms, and more specifically within 
TABLE 5 | Isotopic analysis of CBM production waters.

\begin{tabular}{|c|c|c|c|c|c|c|c|c|c|c|}
\hline \multirow[b]{2}{*}{ Site ID } & \multicolumn{2}{|c|}{ Water stabel isotopes } & \multicolumn{5}{|c|}{ Gas stable isotopes } & \multicolumn{3}{|c|}{ Water age and tracer data } \\
\hline & $\delta^{18} \mathrm{O}-\mathrm{H}_{2} \mathrm{O}$ & $\delta^{2} \mathrm{H}-\mathrm{H}_{2} \mathrm{O}$ & i $\delta^{13} \mathrm{C}-\mathrm{CH}_{4}$ & $\delta^{13} \mathrm{C}-\mathrm{CO}_{2}$ & $\delta^{2} \mathrm{H}-\mathrm{CH}_{4}$ & $\Delta^{13} \mathrm{C}_{\mathrm{CO} 2-\mathrm{CH} 4}$ & $\Delta^{2} \mathrm{H}_{\mathrm{H} 2 \mathrm{O}-\mathrm{CH} 4}$ & $\delta^{13} C_{\text {DIC }}$ & ${ }^{13} \mathrm{C}$ age & pMC \\
\hline AG-13 & - & - & -52.9 & - & -233 & - & - & - & - & - \\
\hline$A G-13^{*}$ & -8.0 & -49 & -53.8 & 10.4 & -216 & 64.2 & 167 & 13.4 & $>50,080$ & 0.196 \\
\hline AG-31 & -8.0 & -50 & -52.9 & - & -226 & - & 176 & 14 & 50,700 & 0.182 \\
\hline AG-31* & -8.2 & -51 & -52.8 & 9.0 & -212 & 61.8 & 161 & 11.7 & 52,200 & 0.151 \\
\hline BB-3* & -7.9 & -48 & -50.1 & - & -216 & - & 168 & 16.8 & 45,860 & 0.331 \\
\hline BV-3 & -8.4 & -51 & -51.3 & - & -230 & - & 179 & 14.7 & 43,200 & 0.462 \\
\hline BV-3* & -8.6 & -54 & -51.7 & - & -223 & - & 169 & 15.7 & $>49,720$ & 0.205 \\
\hline BV-9 & -8.8 & -54 & -50 & - & -231 & - & 177 & 23.4 & 47,900 & 0.257 \\
\hline BV-9* & -9.0 & -56 & -50.4 & 10.8 & -220 & 61.2 & 164 & 19.7 & 54,201 & 0.117 \\
\hline BS-19 & -7.4 & -46 & -56.6 & - & -234 & - & 188 & 18.2 & 43,650 & 0.437 \\
\hline BS-19* & -7.6 & -50 & -57 & - & -223 & - & 173 & 13.3 & 53,250 & 0.132 \\
\hline BS-36 & -8.3 & -51 & -53.6 & - & -226 & - & 175 & 18.8 & 51,550 & 0.163 \\
\hline BS-36* & -8.4 & -53 & -53.8 & 9.6 & -215 & 63.4 & 162 & 13.9 & 53,840 & 0.123 \\
\hline CD-8* & -7.4 & -47 & -49.9 & - & -224 & - & 177 & 15.1 & 45,900 & 0.330 \\
\hline CX-10* & -7.2 & -43 & -44.5 & 11.0 & -217 & 55.5 & 174 & 25.9 & 52,490 & 0.145 \\
\hline PK-28* & -7.4 & -45 & -49.5 & 6.2 & -209 & 55.7 & 164 & 14.6 & 36,800 & 1.020 \\
\hline WP-3 & -7.8 & -47 & - & - & - & - & - & - & - & - \\
\hline WP-3* & -7.6 & -46 & -49.4 & 10.0 & -216 & 59.4 & 170 & 14.2 & 47,680 & 0.264 \\
\hline
\end{tabular}

Reproduced with permission from Baublys et al. (2015). An asterisk indicates that the measurements were taken at the same time as samples for microbial analysis.

the Phycisphaerae (Lage and Bondoso, 2014). For example, Algisphaera agarilytica, isolated from the surface of macroalgae, was shown to use agar, a galactose polymer, as a carbon source (Yoon et al., 2014), and Tepidisphaera mucosa, isolated from a hot spring, was shown to utilize pectin, galactomannon (i.e., locus bean gum), xylose, and galactose, but not xylan (Kovaleva et al., 2014). The Phycisphaerae-PK28 genome is consistent with these previous observations for members of the Phycisphaerae.

In contrast, very little is known about the ecology of the Aminicenantes, as no cultured representatives exist for direct characterization and metabolic analysis of three publicly available genome sequences has been extremely limited (Rinke et al., 2013; Gies et al., 2014; Sharon et al., 2015). Efforts to isolate the Aminicenantes or genomically characterize representative taxa are hampered by their low abundance in most communities. Previous analysis of over 3100 16S rRNA gene amplicon datasets mined from NCBI's sequence read archive (SRA) showed that the Aminicenantes were present in a quarter of all datasets, but they did not exceed $1 \%$ relative abundance in $>99 \%$ of the data sets examined (Farag et al., 2014). Although present at low relative abundance, the Aminicenantes were identified frequently in fresh water, marine, and hydrocarbon-impacted environments, leading researchers to speculate on their role in these environments (Farag et al., 2014). Limited metabolic reconstruction of an Aminicenantes genome recovered from an acetate contaminated aquifer (Rifle, Colorado, U.S.A) revealed that it contained several glycosyl hydrolases (Sharon et al., 2015), but no investigation of the function of those genes was conducted. It was concluded that the Rifle Creek Aminicenantes may degrade carbon through either fermentation or aerobic respiration based on the presence of genes involved in aerobic respiration (respiratory Complex I,
II, and III). This microorganism is also proposed to participate in hydrogen metabolism and assimilatory sulfite reduction. Analysis of a separate Aminicenantes genome recovered from Sakinaw Lake (Canada) revealed a partial set of genes for the WoodLjungdahl pathway (Gies et al., 2014). The authors speculated that the Sakinaw Lake Aminicenantes is capable of using this pathway in reverse to consume acetate and generate $\mathrm{CO}_{2}$ in syntrophic association with a hydrogenotrophic methanogen. In contrast to these previous findings, the population genome of Aminicenantes-PK28 does not indicate that it has the ability to perform aerobic respiration or produce $\mathrm{CO}_{2}$ via the WoodLjungdahl pathway. Instead, Aminicenantes-PK28 appeared to be capable only of anaerobic carbohydrate and amino-acid fermentation, producing $\mathrm{CO}_{2}$ through the oxidation of formate. Interestingly, a broad range of peptidase families were identified in Aminicenantes-PK28, suggesting that amino acid fermentation may be a key feature of its metabolism. For example, peptidases from family M23 capable of lysing the cell walls of other bacteria were identified in Aminicenantes-PK28 and may indicate that this microorganism acts as a scavenger of dead cells in CBM formation waters.

In this study, we have shown compelling evidence that specific additives within the hydraulic fracture fluid are responsible for a major shift in community composition which favors the enrichment of microorganisms from the rare biosphere that are able to utilize galactomannan. The observed enrichment of novel representatives of the class Phycisphaerae and candidate phylum Aminicenantes may also be coupled to their ability to work in syntrophic association with hydrogenotrophic methanogens and to the introduction of specific biocides into the well. It is possible that Aminicenantes and Phycisphaerae-PK28 are resistant to the 
Kathon biocide used in PK-28. Their resistance may result from the lack of genes known to be targeted by this biocide. Although both microorganisms possess 2-oxoglutarate dehydrogenase, other pathways may be used to accommodate its inhibition. For example, aspartate transaminase could be used to generate oxaloacetate for use in the TCA cycle. In addition, the unique cell wall structure of members of the phylum Planctomycetes (Fuerst and Sagulenko, 2011; Devos, 2014) may confer resistance to membrane disruption by Kathon. However, it is also possible, and perhaps more likely, that neither microorganism is biocide resistant, and instead may have simply recolonized the seam after the Kathon had degraded or dispersed to a low concentration. In this case, microorganisms best able to efficiently utilize guar as a carbon substrate would recolonize more quickly.

In addition to PK-28, wells WP-3, and AG-13 also appeared to cluster away from the other wells (Figure 3), indicating that they harbor atypical microbial communities compared to the rest of the Surat Basin. Neither of these wells were subjected to hydrofracture stimulation and neither showed enrichment in either Phycisphaerae or Aminicenantes lineages. Instead, both wells showed enrichment in thermophilic members of the bacterial family Thermodesulfovibrio and archaeal genus of methanogens Methanothermobacter, as well as members of the class OPB41 from the Actinobacteria. The observed enrichment in Thermodesulfovibrio and Methanothermobacter in wells with considerably higher than average temperatures $\left(>40^{\circ} \mathrm{C}\right)$ is consistent with the optimum growth range of these lineages (Henry et al., 1994; Wasserfallen et al., 2000). Therefore, it is likely that these wells are atypical because their temperature is conducive to the enrichment of thermophiles. Additionally, WP-3 displayed a number of geochemical parameters such as $\mathrm{pH}$, conductivity, and total iron that could be responsible for the observed microbial community shift. Additional basin-wide surveys are needed to identify the geochemical factors that govern CBM microbial community structure.

\section{REFERENCES}

Abed, R. M., Al Kharusi, S., Schramm, A., and Robinson, M. D. (2010). Bacterial diversity, pigments and nitrogen fixation of biological desert crusts from the Sultanate of Oman. FEMS Microbiol. Ecol. 72, 418-428. doi: 10.1111/j.15746941.2010.00854.x

Abed, R. M., Musat, N., Musat, F., and Mußmann, M. (2011). Structure of microbial communities and hydrocarbon-dependent sulfate reduction in the anoxic layer of a polluted microbial mat. Mar. Pollut. Bull. 62, 539-546. doi: 10.1016/j.marpolbul.2010.11.030

Altschul, S. F., Madden, T. L., Schäffer, A. A., Zhang, J., Zhang, Z., Miller, W., et al. (1997). Gapped BLAST and PSI-BLAST: a new generation of protein database search programs. Nucleic Acids Res. 25, 3389-3402. doi: 10.1093/nar/25. 17.3389

Australian Department of the Environment (2014). Hydraulic Fracturing ('Fraccing') Techniques, Including Reporting Requirements and Governance Arrangements. Candberra: Commonwealth of Australia.

Baublys, K., Hamilton, S., Golding, S., Vink, S., and Esterle, J. (2015). Microbial controls on the origin and evolution of coal seam gases and production waters of the Walloon Subgroup; Surat Basin, Australia. Int. J. Coal Geol. 147, 85-104. doi: 10.1016/j.coal.2015.06.007

Desantis, T. Z., Hugenholtz, P., Larsen, N., Rojas, M., Brodie, E. L., Keller, K., et al. (2006). Greengenes, a chimera-checked 16S rRNA gene database and
This study provides a basis for understanding how specific additives commonly used in hydraulic fracture fluid may alter CBM microbial communities. However, it is important to note that the findings of this study are specific to the set of additives used and may not be applicable to all CBM wells. Further, only one hydrofractured well was available for sampling. Therefore, examination of additional hydraulically fractured CBM production wells will be necessary to confirm these findings and determine how the microbial community will be affected under different stimulation scenarios. A longitudinal study is also warranted to document the community composition before and for several months after hydraulic fracture stimulation to determine if the community is capable of returning to an unperturbed state.

\section{AUTHOR CONTRIBUTIONS}

SR, PE, DP, SG, and GT all contributed to the study design and helped to draft the manuscript. PE participated in sample collection and contributed to the analysis of the data. DP contributed to the bioinformatic analysis of this work, particularly in the area of population genome binning. All authors approved the final manuscript.

\section{ACKNOWLEDGMENTS}

We thank M. Butler and S. Low for library preparation and sequencing and the numerous Santos and Queensland Gas Company (QGC) staff for access to CBM wells for formation water collections. This study is supported by the Australian Research Council (ARC) through a Linkage Project (LP100200730), QGC- BG Group Business, Santos Ltd, and Total SA. SR is supported by an Australian Postgraduate Award Industry (APAI) scholarship. DP was supported by the Natural Sciences and Engineering Council of Canada. GT is supported by an ARC Queen Elizabeth II Fellowship (DP1093175).

workbench compatible with ARB. Appl. Environ. Microbiol. 72, 5069-5072. doi: 10.1128/AEM.03006-05

Devos, D. P. (2014). PVC bacteria: variation of, but not exception to, the Gramnegative cell plan. Trends Microbiol. 22, 14-20. doi: 10.1016/j.tim.2013.10.008

Dixon, P. (2003). VEGAN, a package of R functions for community ecology. J. Vegetation Sci. 14, 927-930. doi: 10.1111/j.1654-1103.2003.tb02228.x

Evans, P. N., Parks, D. H., Chadwick, G. L., Robbins, S. J., Orphan, V. J., Golding, S. D., et al. (2015). Methane metabolism in the archaeal phylum bathyarchaeota revealed by genome-centric metagenomics. Science 350, 434-438. doi: 10.1126/science.aac7745

Farag, I. F., Davis, J. P., Youssef, N. H., and Elshahed, M. S. (2014). Global patterns of abundance, diversity and community structure of the Aminicenantes (candidate phylum OP8). PLoS ONE 9:e92139. doi: 10.1371/journal.pone.0092139

Finn, R. D., Clements, J., and Eddy, S. R. (2011). HMMER web server: interactive sequence similarity searching. Nucleic Acids Res. 367, W29-W37. doi: 10.1093/nar/gkr367

Finn, R. D., Miller, B. L., Clements, J., and Bateman, A. (2014). iPfam: a database of protein family and domain interactions found in the Protein Data Bank. Nucleic Acids Res. 42, D364-D373. doi: 10.1093/nar/gkt1210

Fuerst, J. A., and Sagulenko, E. (2011). Beyond the bacterium: planctomycetes challenge our concepts of microbial structure and function. Nat. Rev. Microbiol. 9, 403-413. doi: 10.1038/nrmicro2578 
Fukunaga, Y., Kurahashi, M., Sakiyama, Y., Ohuchi, M., Yokota, A., and Harayama, S. (2009). Phycisphaera mikurensis gen. nov., sp. nov., isolated from a marine alga, and proposal of Phycisphaeraceae fam. nov., Phycisphaerales ord. nov. and Phycisphaerae classis nov. in the phylum Planctomycetes. J. Gen. Appl. Microbiol. 55, 267-275. doi: 10.2323/jgam.55.267

Gies, E. A., Konwar, K. M., Beatty, J. T., and Hallam, S. J. (2014). Illuminating microbial dark matter in meromictic Sakinaw Lake. Appl. Environ. Microbiol. 80, 6807-6818. doi: 10.1128/AEM.01774-14

Golding, S. D., Boreham, C. J., and Esterle, J. S. (2013). Stable isotope geochemistry of coal bed and shale gas and related production waters: a review. Int. J. Coal Geol. 120, 24-40. doi: 10.1016/j.coal.2013.09.001

Haft, D. H., Selengut, J. D., Richter, R. A., Harkins, D., Basu, M. K., and Beck, E. (2013). TIGRFAMs and genome properties in 2013. Nucleic Acids Res. 41, D387-D395. doi: 10.1093/nar/gks1234

Hamilton, S. K., Golding, S. D., Baublys, K. A., and Esterle, J. S. (2014). Stable isotopic and molecular composition of desorbed coal seam gases from the Walloon Subgroup, eastern Surat Basin, Australia. Int. J. Coal Geol. 122, 21-36. doi: 10.1016/j.coal.2013.12.003

Henry, E., Devereux, R., Maki, J., Gilmour, C., Woese, C., Mandelco, L., et al. (1994). Characterization of a new thermophilic sulfate-reducing bacterium. Arch. Microbiol. 161, 62-69. doi: 10.1007/BF00248894

Hoehler, T. M., and Jørgensen, B. B. (2013). Microbial life under extreme energy limitation. Nat. Rev. Microbiol. 11, 83-94. doi: 10.1038/nrmicro2939

Hyatt, D., Chen, G. L., Locascio, P. F., Land, M. L., Larimer, F. W., and Hauser, L. J. (2010). Prodigal: prokaryotic gene recognition and translation initiation site identification. BMC Bioinformatics 11:119. doi: 10.1186/1471-2105-11-119

Kovaleva, O. L., Merkel, A., Novikov, A., Baslerov, R., Toshchakov, S., and Bonch-Osmolovskaya, E. A. (2014). Tepidisphaera mucosa gen. nov., sp. nov., a new moderately thermophilic member of Phycisphaerae class in the Planctomycetes, and proposal of a new family Tepidisphaeraceae and a new order Tepidisphaerales. Int. J. Syst. Evol. Microbiol. 65(Pt 2), 549-555. doi: 10.1099/ijs.0.070151-0

Lage, O. M., and Bondoso, J. (2011). Planctomycetes diversity associated with macroalgae. FEMS Microbiol. Ecol. 78, 366-375. doi: 10.1111/j.15746941.2011.01168.x

Lage, O. M., and Bondoso, J. (2014). Planctomycetes and macroalgae, a striking association. Front Microbiol. 5:267. doi: 10.3389/fmicb.2014.00267

Legendre, P., and Gallagher, E. (2001). Ecologically meaningful transformations for ordination of species data. Oecologia 129, 271-280. doi: 10.1007/s004420100716

Ludwig, W., Strunk, O., Westram, R., Richter, L., Meier, H., Buchner, A., et al. (2004). ARB: a software environment for sequence data. Nucleic Acids Res. 32, 1363-1371. doi: 10.1093/nar/gkh293

Markowitz, V. M., Chen, I.-M. A., Palaniappan, K., Chu, K., Szeto, E., Grechkin, Y., et al. (2012). IMG: the integrated microbial genomes database and comparative analysis system. Nucleic Acids Res. 40, D115-D122. doi: 10.1093/nar/gkr1044

Onstott, T., Magnabosco, C., Aubrey, A., Burton, A., Dworkin, J., Elsila, J., et al. (2014). Does aspartic acid racemization constrain the depth limit of the subsurface biosphere? Geobiology 12, 1-19. doi: 10.1111/gbi.12069

Orem, W., Tatu, C., Varonka, M., Lerch, H., Bates, A., Engle, M., et al. (2014). Organic substances in produced and formation water from unconventional natural gas extraction in coal and shale. Int. J. Coal Geol. 126, 20-31. doi: 10.1016/j.coal.2014.01.003

Parks, D. H., Imelfort, M., Skennerton, C. T., Hugenholtz, P., and Tyson, G. W. (2015). CheckM: assessing the quality of microbial genomes recovered from isolates, single cells, and metagenomes. Genome Res. 25, 1043-1055. doi: 10.1101/gr.186072.114

Parks, D. H., Tyson, G. W., Hugenholtz, P., and Beiko, R. G. (2014). STAMP: statistical analysis of taxonomic and functional profiles. Bioinformatics 30, 3123-3124. doi: 10.1093/bioinformatics/btu494

Price, M. N., Dehal, P. S., and Arkin, A. P. (2010). FastTree 2-approximately maximum-likelihood trees for large alignments. PLoS ONE 5:e9490. doi: 10.1371/journal.pone.0009490

R Core Team (2013). A Language and Environment for Statistical Computing. Available online at: http://www.R-project.org/

Rawlings, N. D., Waller, M., Barrett, A. J., and Bateman, A. (2014). MEROPS: the database of proteolytic enzymes, their substrates and inhibitors. Nucleic Acids Res. 42, D503-D509. doi: 10.1093/nar/gkt953
Rinke, C., Schwientek, P., Sczyrba, A., Ivanova, N. N., Anderson, I. J., Cheng, J.-F., et al. (2013). Insights into the phylogeny and coding potential of microbial dark matter. Nature 499, 431-437. doi: 10.1038/nature 12352

Scott, A. R. (2002). Hydrogeologic factors affecting gas content distribution in coal beds. Int. J. Coal Geol. 50, 363-387. doi: 10.1016/S0166-5162(02)00135-0

Seemann, T. (2014). Prokka: rapid prokaryotic genome annotation. Genome Anal. 30, 2068-2069. doi: 10.1093/bioinformatics/btu153

Sharon, I., Kertesz, M., Hug, L. A., Pushkarev, D., Blauwkamp, T. A., Castelle, C. J., et al. (2015). Accurate, multi-kb reads resolve complex populations and detect rare microorganisms. Genome Res. 25, 534-543. doi: 10.1101/gr.183012.114

Soo, R. M., Skennerton, C. T., Sekiguchi, Y., Imelfort, M., Paech, S. J., Dennis, P. G., et al. (2014). An expanded genomic representation of the phylum Cyanobacteria. Genome Biol. Evol. 6, 1031-1045. doi: 10.1093/gbe/evu073

Stamatakis, A. (2006). RAxML-VI-HPC: maximum likelihood-based phylogenetic analyses with thousands of taxa and mixed models. Bioinformatics 22, 2688-2690. doi: 10.1093/bioinformatics/btl446

Strąpoć, D., Mastalerz, M., Dawson, K., Macalady, J., Callaghan, A. V., Wawrik, B., et al. (2011). Biogeochemistry of microbial coal-bed methane. Annu. Rev. Earth Planet. Sci. 39, 617-656. doi: 10.1146/annurev-earth-040610-133343

Struchtemeyer, C. G., and Elshahed, M. S. (2012). Bacterial communities associated with hydraulic fracturing fluids in thermogenic natural gas wells in North Central Texas, USA. FEMS Microbiol. Ecol. 81, 13-25. doi: 10.1111/j.15746941.2011.01196.x

Suzek, B. E., Huang, H., McGarvey, P., Mazumder, R., and Wu, C. H. (2007). UniRef: comprehensive and non-redundant UniProt reference clusters. Bioinformatics 23, 1282-1288. doi: 10.1093/bioinformatics/btm098

Tatusov, R. L., Fedorova, N. D., Jackson, J. D., Jacobs, A. R., Kiryutin, B., Koonin, E. V., et al. (2003). The COG database: an updated version includes eukaryotes. $B M C$ bioinformatics 4:41. doi: 10.1186/1471-2105-4-41

Tekere, M., Lötter, A., Olivier, J., Jonker, N., and Venter, S. (2013). Metagenomic analysis of bacterial diversity of Siloam hot water spring, Limpopo, South Africa. Afr. J. Biotechnol. 10, 18005-18012. doi: 10.5897/AJB11.899

U.S. Energy Information Administration (2013). Annual Energy Outlook 2013 with Projection to 2040. Washington, DC: U.S. Department of Energy. Available online at: http://www.eia.gov/forecasts/aeo

Wasserfallen, A., Nölling, J., Pfister, P., Reeve, J., and De Macario, E. C. (2000). Phylogenetic analysis of 18 thermophilic Methanobacterium isolates supports the proposals to create a new genus, Methanothermobacter gen. nov., and to reclassify several isolates in three species, Methanothermobacter thermautotrophicus comb. nov., Methanothermobacter wolfeii comb. nov., and Methanothermobacter marburgensis sp. nov. Int. J. Syst. Evol. Microbiol. 50, 43-53. doi: 10.1099/00207713-50-1-43

Williams, T. M. (2007). The mechanism of action of isothiazolone biocides. Power Plant Chem. 9, 14.

Yakimov, M. M., Cappello, S., Crisafi, E., Tursi, A., Savini, A., Corselli, C., et al. (2006). Phylogenetic survey of metabolically active microbial communities associated with the deep-sea coral Lophelia pertusa from the Apulian plateau, Central Mediterranean Sea. Deep Sea Res. 53, 62-75. doi: 10.1016/j.dsr.2005.07.005

Yin, Y., Mao, X., Yang, J., Chen, X., Mao, F., and Xu, Y. (2012). dbCAN: a web resource for automated carbohydrate-active enzyme annotation. Nucleic Acids Res. 40, W445-W451. doi: 10.1093/nar/gks479

Yoon, J., Jang, J.-H., and Kasai, H. (2014). Algisphaera agarilytica gen. nov., sp. nov., a novel representative of the class Phycisphaerae within the phylum Planctomycetes isolated from a marine alga. Antonie Van Leeuwenhoek 105, 317-324. doi: 10.1007/s10482-013-0076-1

Conflict of Interest Statement: The authors declare that the research was conducted in the absence of any commercial or financial relationships that could be construed as a potential conflict of interest.

Copyright $(2016$ Robbins, Evans, Parks, Golding and Tyson. This is an open-access article distributed under the terms of the Creative Commons Attribution License (CC $B Y)$. The use, distribution or reproduction in other forums is permitted, provided the original author(s) or licensor are credited and that the original publication in this journal is cited, in accordance with accepted academic practice. No use, distribution or reproduction is permitted which does not comply with these terms. 